\title{
Developmentally-Regulated GTP-Binding Protein 2
}

National Cancer Institute

\section{Source}

National Cancer Institute. Developmentally-Regulated GTP-Binding Protein 2. NCI

Thesaurus. Code C125553.

Developmentally-regulated GT P-binding protein 2 (364 aa, $\sim 41 \mathrm{kDa}$ ) is encoded by the human DRG2 gene. This protein is involved in cell proliferation and cell differentiation. 